\title{
Flavonoids and Essential Oil of Bidens cernua of Polish Origin and in vitro Antimicrobial Activity of the Oil
}

\section{Monika Tomczykowa $^{* 1}$, Michał Tomczyk ${ }^{2}$, Katarzyna Leszczyńska ${ }^{3}$ and Danuta Kalemba ${ }^{4}$}

\author{
${ }^{1}$ Department of Organic Chemistry, Faculty of Pharmacy, Medical University of Biatystok, ul. \\ Mickiewicza 2a, 15-222 Biatystok, Poland \\ ${ }^{2}$ Department of Pharmacognosy, Faculty of Pharmacy, Medical University of Biatystok, \\ ul. Mickiewicza 2a, 15-230 Biatystok, Poland \\ ${ }^{3}$ Department of Microbiology, Faculty of Medicine, Medical University of Biatystok, \\ ul. Mickiewicza 2a, 15-222 Biatystok, Poland \\ ${ }^{4}$ Institute of General Food Chemistry, Faculty of Biotechnology and Food Sciences, \\ Lodz University of Technology, ul. Stefanowskiego 4/10, 90-924 Lódź, Poland
}

(Received September 9 2016; Revised March 28, 2017; Accepted April 10, 2017)

\begin{abstract}
Phytochemical studies of the aerial parts of Bidens cernua L. led to the isolation of six flavonoids: luteolin (1), flavanomarein (2), tilianin (3), maritimetin (4), cynaroside (5) and cosmosiin (6). The quantitative analysis of flavonoids exhibited $0.81 \%$ contents of flavonoids in flowers and $1.62 \%$ in the herb counted as a hyperoside equivalent. Total Tannins Content showed the occurrence of $7.87 \%$ in flowers and $5.83 \%$ in the herb. The chemical composition of the essential oil obtained from the herb of B. cernua was evaluated in $92.2 \%$, which corresponds to 99 compounds. Antimicrobial activity of the essential oil was evaluated on Gram-positive, Gram-negative bacteria and fungi. The oil exhibited a strong antibacterial and antifungal activity, especially against Gram-positive bacterial strains. This is the first time the aforementioned compound (3) has been isolated from B. cernua.
\end{abstract}

Keywords: Bidens cernua; Asteraceae; phytochemical analysis; flavonoids; essential oil; antimicrobial activity. (C) 2017 ACG Publications. All rights reserved.

\section{Plant Source}

The aerial parts of flowering plants of Bidens cernua L. (Asteraceae) were collected at the beginning of September 2009 south-east region of Poland, dried at room temperature and finely cutted. A voucher specimen (No. BC 03001) has been deposited at the Herbarium of the Department of Pharmacognosy, Medical University of Białystok, Poland.

\footnotetext{
* Corresponding author: E- Mail: monika.tomczyk@umb.edu.pl, Phone +48-85-748-5641

The article was published by ACG Publications 


\section{Previous Studies}

Previous phytochemical reports on $B$. cernua have revealed the presence of secondary plant metabolites such as polyacetylenes, sesquiterpenes, essential oil and flavonoids [1-5]. In continuation of our interest in the phytochemistry of plants from genus Bidens growing in Poland we decided to carry out a phytochemical studies on the herb and flowers of B. cernua of Polish origin.

\section{Present Study}

To isolate the flavonoid compounds, the diethyl ether, ethyl acetate and butanolic extracts were subjected to subsequent column chromatography on polyamide as stationary phase with eluting solvent systems of increasing polarity. As a result of series isolation procedures and purification on Sephadex LH-20, compounds 1-6 were obtained. The known isolates were confirmed as luteolin (1) [6], flavanomarein (isookanin 7-O- $\beta$-D-glucopyranoside) (2) [7], maritimetin (4) [8], cynaroside (luteolin 7-O- $\beta$-D-glucopyranoside) (5) [6] and cosmosiin (apigenin 7-O- $\beta$-D-glucopyranoside) (6) [8] by the comparison of reported spectral and physical data. To the best of authors knowledge, this is the first report on the isolation of tilianin (acacetin 7-O- $\beta$-D-glucopyranoside) (3) from B. cernua.

Structure elucidation of compound 3: Compound 3 was isolated as a light yellow solid. The UV spectrum showed the characteristic flavonoid bands at 268 and $324 \mathrm{~nm}$ [9]. It showed the presence of free - $\mathrm{OH}$ group at $\mathrm{C}-5$. On addition of NaOAc no apparent shift of the band at $268 \mathrm{~nm}$ was observed, suggesting the blocked -OH group at $\mathrm{C}-7$ by a glycosidic linkage. The ${ }^{1} \mathrm{H}-\mathrm{NMR}$ spectrum, indicated the presence of flavonoid moiety and a sugar group. In the ${ }^{1} \mathrm{H}-\mathrm{NMR}$ (DMSO,400 MHz), the observed signals from protons were assigned as follow: $\delta: 6.96(1 \mathrm{H}, \mathrm{s}, \mathrm{H}-3), 6.46(1 \mathrm{H}, \mathrm{d}, \mathrm{J}=2.1, \mathrm{H}-6), 6.86(1 \mathrm{H}$, d, J=2.1, H-8), 8.07 (2H, d, J=8.9, H-2', H-6'), 7.13 (2H, d, J=8.9, H-3', H-5'), 3.87 (3H, s, H-OCH $\left.3^{-} 4^{\prime}\right)$ to flavonoid skeleton. The anomeric proton signal $\mathrm{H}-1$ " $(\delta 5.07)$ of glucose $(\mathrm{d}, \mathrm{J}=7.2 \mathrm{~Hz})$ revealed the existence of $\beta$-glycosidic linkage between the aglycone and sugar. The results suggest that the isolated compound 3 exhibited a close resemblance with that of reported compound, tilianin [6]

Chemotaxonomic evaluation: From a chemotaxonomic point of view, the identification in the genus Bidens L. of derivatives of flavonoids confirms the general chemical homogeneity regarding this class of compounds inside the genus. The presence of flavonoid aglycones, in particular luteolin, has been reported in aerial parts of many species: B. frondosa, B. parviflora, B. pilosa and B. tripartita $[7,10$ 13]. Similarly to flavonoid aglycones, the glycosylated derivatives have been used as chemotaxonomic markers in the genus Bidens. Glycosylation at C-7 of those compounds has been found to be the most frequent substitution. The presence of 7-O-glucosides of apigenin and luteolin in Bidens species such as B. tripartita or $B$. frondosa has been reported [11, 14]. The presence of hydroxyaurones and chalcones such as maritimetin and flavanomarein in Bidens species (B. andina, B. ferulifolia) has an important meaning and has been described as main polyphenolics in the genus $[15,16]$.

Total Flavonoid Content (TFC): The total content of flavonoids in flowers and herb of B. cernua was based on the Christ-Müller's method [17] with modifications according to Polish Pharmacopoeia $10^{\text {th }}$ [18]. The results obtained for flowers showed the presence of $0.81 \%$ of flavonoids counted as hyperoside and $0.57 \%$ of flavonoid compounds expressed as quercetin. The results for the herb were $1.62 \%$ and $1.13 \%$, respectively.

Total Tannins Content (TTC): The quantitative analysis of tannins was made according to hide powder weight method described in DAB10 [19]. TTC content (expressed in equivalents/100 g of dry weight) was higher by more than $2 \%$ in flowers $(7.87 \%)$ than in the herb $(5.83 \%)$.

Essential oil preparation: Dried at room temperature and finely cut herb (500 g) was hydrodistilled for 3h using Clevenger-type apparatus [18] to yield limpid essential oil, with light-yellow colour and an intensive, but unpleasant scent, in the quantity of $0.5 \mathrm{~mL}(0.10 \% \mathrm{v} / \mathrm{w})$. 
Identification of essential oil component: After detailed analyses of GC and GC-MS data, 99 constituents were totally identified (Table 1), which corresponds to $92.2 \%[20,21]$. The main components of the tested essential oil are oxygenated monoterpenes, sesquiterpene hydrocarbons and monoterpene hydrocarbons. According to previous studies B. cernua herb oil was rich in polyacetylenes and especially 1 -phenylhepta-1,3,5-triyn $[3,4]$ that was absent in researched oil. The other compounds identified in the oil are in good accordance with data published for B. cernua [4]. The differences are based on quantitative, not qualitative content. The presence of $\beta$-caryophyllene, $\delta$ cadinene, humulene epoxide II as main constituents has been confirmed for essential oils from flowers of B. pilosa and B. tripartita $[22,23]$. Due to the heterogeneity of the compounds identified in the Bidens species, it is difficult to establish a characteristic pattern of compounds for the genus. Variability in the composition of essential oils derived from plants of different origin is common phenomenon and may be due to the varied climatic conditions of the regions as well as the method for drying and storing the raw material and the time elapsed from harvest to distillation of essential oil [24-27].

Table 1. Chemical composition of essential oil of B. cernua herb

\begin{tabular}{|c|c|c|c|c|}
\hline $\begin{array}{l}\text { Peak } \\
\text { No }\end{array}$ & Compound $^{1}$ & $\begin{array}{l}\text { Content } \\
(\%)\end{array}$ & $\overline{\mathbf{R I}}$ & RI lit. $^{2}$ \\
\hline 1. & Hexanal & 0.4 & 777 & $769-775^{a, b}$ \\
\hline 2. & Octane & 0.1 & 800 & 800 \\
\hline 3. & Furfural & 0.1 & 809 & $794-800^{a, b}$ \\
\hline 4. & (E)-Hex-2-enal & 0.3 & 829 & $832-850^{\mathrm{a}, \mathrm{c}}$ \\
\hline 5. & $\alpha$-Thujene & 0.1 & 925 & $926-932^{\mathrm{a}, \mathrm{c}}$ \\
\hline 6. & $\alpha$-Pinene & 2.3 & 932 & $931-936^{\mathrm{a}-\mathrm{c}}$ \\
\hline 7. & Benzaldehyde & 0.7 & 935 & $927-941^{\mathrm{a}, \mathrm{b}}$ \\
\hline 8. & Camphene & 0.4 & 946 & $950^{\mathrm{a}, \mathrm{c}}$ \\
\hline 9. & Thuja-2,4(10)-diene & 0.1 & 949 & $946-957^{\mathrm{a}, \mathrm{b}}$ \\
\hline 10. & 6-Methylhept-5-en-2-one & 0.2 & 965 & $963-978^{\mathrm{a}, \mathrm{b}}$ \\
\hline 11. & Oct-1-en-3-ol & 0.1 & 968 & $959-963^{\mathrm{a}, \mathrm{b}}$ \\
\hline 12. & $\beta$-Pinene & $\mathrm{t}$ & 973 & $970-978^{\mathrm{a}, \mathrm{b}}$ \\
\hline 13. & 2-Pentylfuran & 0.5 & 981 & $977-981^{\mathrm{a}, \mathrm{b}}$ \\
\hline 14. & Myrcene & 0.4 & 983 & $979-987^{\mathrm{a}-\mathrm{c}}$ \\
\hline 15. & cis-2-(Pent-2-enyl)furan & 0.3 & 988 & $983^{\mathrm{b}}$ \\
\hline 16. & $\alpha$-Phellandrene & 0.6 & 999 & $997-1002^{a-c}$ \\
\hline 17. & $\alpha$-Terpinene & 0.7 & 1011 & $1008-1013^{\mathrm{a}, \mathrm{b}}$ \\
\hline 18. & p-Cymene & 2.7 & 1014 & $1015^{\mathrm{a}, \mathrm{c}}$ \\
\hline 19. & $\beta$-Phellandrene ${ }^{3}$ & 0.4 & 1024 & $1023-1025^{\mathrm{a}, \mathrm{b}}$ \\
\hline 20. & Limonene $e^{3}$ & 0.2 & 1024 & $1020-1025^{\mathrm{a}, \mathrm{b}}$ \\
\hline 21. & $(Z)$ - $\beta$-Ocimene & 2.5 & 1028 & $1024-1029^{\mathrm{a}, \mathrm{b}}$ \\
\hline 22. & (E)- $\beta$-Ocimene & 0.2 & 1040 & $1034-1041^{\mathrm{a}, \mathrm{b}}$ \\
\hline 23. & $\gamma$-Terpinene & 1.6 & 1052 & $1047-1051^{\mathrm{a}, \mathrm{b}}$ \\
\hline 24. & trans-Sabinene hydrate & 0.2 & 1057 & $1050-1053^{\mathrm{a}, \mathrm{b}}$ \\
\hline 25. & trans-Linalol oxide (furanoid) & 0.7 & 1061 & $1045-1068^{a, b}$ \\
\hline 26. & cis-Linalol oxide (furanoid) & 0.3 & 1075 & $1064-1072^{\mathrm{a}, \mathrm{b}}$ \\
\hline 27. & p-Cymenene & 0.3 & 1078 & $1061-1075^{\mathrm{a}, \mathrm{b}}$ \\
\hline 28. & Nonanal & 0.6 & 1084 & $1077-1091^{\mathrm{a}, \mathrm{b}}$ \\
\hline 29. & Linalool & 7.6 & 1086 & $1081-1086^{\mathrm{a}, \mathrm{b}}$ \\
\hline 30. & Hotrienol & 4.3 & 1088 & $1083-1089^{\mathrm{a}, \mathrm{b}}$ \\
\hline 31. & Perillene & 0.9 & 1090 & $1086-1090^{\mathrm{a}, \mathrm{b}}$ \\
\hline 32. & $\alpha$-Campholenal & 0.1 & 1102 & $1105-1114^{\mathrm{a}, \mathrm{b}}$ \\
\hline 33. & cis-p-Menth-2-en-1-ol & 0.4 & 1107 & $1106-1011^{\mathrm{a}-\mathrm{c}}$ \\
\hline 34. & trans-p-Mentha-2,8-dien-1-ol & 0.2 & 1111 & $1113^{\mathrm{a}}$ \\
\hline 35. & cis-allo-Ocimene & 0.9 & 1121 & $1117-1126^{\mathrm{a}, \mathrm{b}}$ \\
\hline 36. & cis-p-Mentha-2,8-dien-1-ol & 0.1 & 1128 & $1116-1123^{\mathrm{a}, \mathrm{b}}$ \\
\hline 37. & cis-Verbenol & 0.3 & 1131 & $1128-1132^{\mathrm{a}-\mathrm{c}}$ \\
\hline 38. & trans-Verbenol & 0.3 & 1134 & $1136-1144^{\mathrm{a}, \mathrm{b}}$ \\
\hline 39. & (E)-Non-2-enal & 0.1 & 1141 & $1139^{\mathrm{a}}$ \\
\hline
\end{tabular}




\begin{tabular}{|c|c|c|c|}
\hline 40. Isoborneol & 0.2 & 1151 & $1142-1146^{\mathrm{a}, \mathrm{b}}$ \\
\hline 41. Borneol & 0.2 & 1154 & $1148-1150^{\mathrm{a}, \mathrm{b}}$ \\
\hline 42. p-Cymen-9-ol & $\mathrm{t}$ & 1162 & $1158^{\mathrm{a}}$ \\
\hline 43. Terpinen-4-ol & 3.5 & 1167 & $1161-1164^{a, b}$ \\
\hline 44. Dill ether & 0.1 & 1173 & $1170-1176^{\mathrm{a}, \mathrm{b}}$ \\
\hline 45. $\alpha$-Terpineol & 1.6 & 1178 & $1172-1176^{\mathrm{a}, \mathrm{b}}$ \\
\hline 46. Myrtenol & 0.4 & 1181 & $1174-1178^{\mathrm{a}, \mathrm{b}}$ \\
\hline 47. Verbenone & 0.4 & 1188 & $1185-1186^{\mathrm{a}, \mathrm{c}}$ \\
\hline 48. $\beta$-Cyclocitral & 0.1 & 1203 & $1195^{\mathrm{a}}$ \\
\hline 49. Nerol & 0.3 & 1216 & $1209-1213^{a, b}$ \\
\hline 50. Neral & 1.0 & 1219 & $1215-1218^{\mathrm{a}, \mathrm{c}}$ \\
\hline 51. Carvone & 0.2 & 1223 & $1213-1218^{a, b}$ \\
\hline 52. Geraniol & 1.4 & 1240 & $1235-1238^{\mathrm{a}, \mathrm{b}}$ \\
\hline 53. Geranial & 1.2 & 1247 & $1244-1249^{a-c}$ \\
\hline 54. 1,1,6-Trimethyl-1,2,3,4-tetrahydronaphthalene & 0.2 & 1253 & $1255^{\mathrm{b}}$ \\
\hline 55. Carvacrol & 4.4 & 1283 & $1278-1282^{\mathrm{a}, \mathrm{c}}$ \\
\hline 56. Eugenol & 0.3 & 1337 & $1331-1333^{\mathrm{a}, \mathrm{c}}$ \\
\hline 57. 1,1,6-Trimethyl-1,2-dihydronaphthalene & 0.3 & 1345 & $1339^{\mathrm{b}}$ \\
\hline 58. $7 \beta \mathrm{H}$-Silphiperfol-5-ene & $\mathrm{t}$ & 1354 & $1348-1352^{\mathrm{a}, \mathrm{b}}$ \\
\hline 59. Silphiperfol-6-ene & 0.3 & 1369 & $1365-1379^{\mathrm{a}, \mathrm{b}}$ \\
\hline 60. $\beta$-Damascenone & $\mathrm{t}$ & 1373 & $1363-1369^{\mathrm{a}, \mathrm{b}}$ \\
\hline 61. Methyleugenol & $\mathrm{t}$ & 1375 & $1369-1371^{\mathrm{a}, \mathrm{b}}$ \\
\hline 62. Anastreptene & 0.7 & 1376 & $1373^{\mathrm{a}}$ \\
\hline 63. $\alpha$-Copaene & 0.1 & 1383 & $1376-1379^{\mathrm{a}, \mathrm{b}}$ \\
\hline 64. $c i s$ - $\beta$-Elemene & 0.3 & 1386 & $1381^{\mathrm{a}}$ \\
\hline 65. $\beta$-Elemene & 7.3 & 1394 & $1389-1397^{\mathrm{a}, \mathrm{b}}$ \\
\hline $\begin{array}{l}\text { 66. 4-(2,6,6,-Trimethylcyclohexa-1,3-dienyl)butan- } \\
\text { 2-one }\end{array}$ & 0.2 & 1404 & $1424^{\mathrm{b}}$ \\
\hline 67. $\beta$-Caryophyllene & 6.7 & 1428 & $1421-1424^{\mathrm{a}, \mathrm{b}}$ \\
\hline 68. Geranylacetone & 0.6 & 1433 & $1426-1430^{\mathrm{a}, \mathrm{b}}$ \\
\hline 69. trans- $\alpha$-Bergamotene & 0.3 & 1439 & $1434^{\mathrm{a}}$ \\
\hline 70. (E)- $\beta$-Farnesene & 2.6 & 1449 & $1446-1448^{\mathrm{a}, \mathrm{b}}$ \\
\hline 71. $\alpha$-Humulene & 3.5 & 1461 & $1454-1456^{\mathrm{a}, \mathrm{b}}$ \\
\hline $\begin{array}{l}\text { 72. 4-(2,4,4-Trimethylcyclohexa-1,5-dienyl)but-3- } \\
\text { en-2-one }\end{array}$ & 0.3 & 1465 & $1460^{\mathrm{b}}$ \\
\hline 73. $\beta$-Ionone & 0.3 & 1471 & $1468^{\mathrm{a}}$ \\
\hline 74. ar-Curcumene & 0.3 & 1476 & $1468-1472^{\mathrm{a}, \mathrm{b}}$ \\
\hline 75. Selina-4,11-diene & 0.4 & 1480 & $1475^{\mathrm{a}}$ \\
\hline 76. trans- $\beta$-Bergamotene & 0.8 & 1484 & $1480^{\mathrm{a}}$ \\
\hline 77. $(Z, E)$ - $\alpha$-Farnesene & 0.6 & 1486 & $1480^{\mathrm{a}}$ \\
\hline 78. $\beta$-Selinene & 1.0 & 1493 & $1486^{\mathrm{a}}$ \\
\hline 79. $(E, E)$ - $\alpha$-Farnesene & 0.4 & 1499 & $1496-1497^{\mathrm{a}, \mathrm{b}}$ \\
\hline 80. $\alpha$-Selinene & 1.4 & 1502 & $1494-1500^{\mathrm{a}, \mathrm{b}}$ \\
\hline 81. $\beta$-Bisabolene & 2.1 & 1507 & $1503-1509^{\mathrm{a}, \mathrm{b}}$ \\
\hline 82. $\gamma$-Cadinene & 0.1 & 1516 & $1507-1512^{\mathrm{a}, \mathrm{b}}$ \\
\hline 83. $\delta$-Cadinene & 0.2 & 1523 & $1520^{\mathrm{a}}$ \\
\hline 84. (Z)-Nerolidol & $\mathrm{t}$ & 1534 & $1522^{\mathrm{a}, \mathrm{b}}$ \\
\hline 85. (E)-Nerolidol & 1.1 & 1552 & $1547-1553^{\mathrm{a}, \mathrm{b}}$ \\
\hline 86. $\beta$-Caryophyllene epoxide & 1.8 & 1584 & $1576-1578^{\mathrm{a}, \mathrm{b}}$ \\
\hline 87. Humulene epoxide II & 1.2 & 1609 & $1602^{\mathrm{a}}$ \\
\hline 88. neo-Intermedeol & 0.4 & 1633 & $1601^{\mathrm{b}}$ \\
\hline 89. Intermedeol & 0.2 & 1637 & $1630-1653^{\mathrm{a}, \mathrm{b}}$ \\
\hline 90. Eudesm-11-en- $4 \alpha$-ol & 0.5 & 1653 & $1641-1649^{\mathrm{a}, \mathrm{b}}$ \\
\hline 91. $\alpha$-Bisabolol & 0.7 & 1675 & $1665-1674^{\mathrm{a}, \mathrm{b}}$ \\
\hline 92. Eugenyl valerate & $\mathrm{t}$ & 1733 & $1728^{\mathrm{b}}$ \\
\hline 93. Methyldibenzothiophene ${ }^{4}$ & 0.1 & 1737 & $1822^{\mathrm{b}}$ \\
\hline 94. Drimenol & 0.2 & 1772 & $1761^{\mathrm{a}, \mathrm{b}}$ \\
\hline 95. Methyldibenzothiophene ${ }^{4}$ & 1.3 & 1781 & $1842^{\mathrm{b}}$ \\
\hline 96. 6,10,14-Trimethypentadecan-2-one & 0.9 & 1833 & $1838^{\mathrm{b}}$ \\
\hline
\end{tabular}


97. Hexadecanol

98. Hexadecanoic acid

99. Phytol

Oxygenated monoterpenes

Sesquiterpene hydrocarbons

Monoterpene hydrocarbons

Oxygenated sesquiterpenes

Others

Total identified
1871

1970

2107 $1864-1866^{\mathrm{a}, \mathrm{b}}$

$1972^{\mathrm{b}}$

$2104-2123^{a, b}$
0.9

30.2

29.1

14.3

6.1

12.5

92.2

$\mathrm{t}-$ traces, $<0.05 \%$

${ }^{1}$ - compounds listed in order of elution from Rtx-1 column

${ }^{2}-$ Retention index of literature a) [28], b) [29], c) [30]

3 - percentages from HP-Innowax column

${ }^{4}$ - correct isomer not identified

Antibacterial and antifungal activities of the essential oil: The biological activity of the essential oil was evaluated on Gram-positive, Gram-negative bacteria and fungi [31-33]. The MIC values received for the essential oil are listed in supporting materials (S3.). The growth of Gram-positive bacteria and fungi was very well inhibited by the oil. The strongest antibacterial influence of the tested oil was noted against $N$. gonorrhoeae $(\mathrm{MIC}=1.56 \mathrm{mg} / \mathrm{mL})$ and $M$. catarrhalis $(\mathrm{MIC}=2.07+/-0.64 \mathrm{mg} / \mathrm{mL})$ two Gram-negative bacterial strains. Moderate inhibitory effect of essential oil was observed on growth of E. faecalis (Gram-positive) and P. aeruginosa (Gram-negative). The rest of tested Gramnegative bacterial strains were rather resistant to essential oil (MIC $>100 \mathrm{mg} / \mathrm{mL}$ ). The highest fungistatic effect was observed for G. candidum (MIC $=3.1 \mathrm{mg} / \mathrm{mL}$ ). The least impact was noted for C. krusei $(\mathrm{MIC}=50.0 \mathrm{mg} / \mathrm{mL})$.

To the best of our knowledge, this is the first report on chemical composition of the herb and on the analysis of volatile constituents and antimicrobial activities of the essential oil from of $B$. cernua gathered on territory of Poland.

\section{Supporting Information}

Supporting Information accompanies this paper on http://www.acgpubs.org/RNP

\section{References}

[1] M.I. Borisov, T.I. Isakova and A.G. Serbin (1979). Flavonoids of Bidens cernua, Chem. Nat. Comp. 15, 197-198.

[2] N. Zhu, X.-W. Li, G.-Y. Liu, X.-L. Shi, M.-Y. Gui, Ch.-Q. Sun and Y.-R. Jin (2009). Constituents from aerial parts of Bidens cernua L. and their DPPH radical scavenging activity, Chem. Res. Chinese Universities 25, 328-331.

[3] N.P. Rybalchenko, V.A. Prykhodko, S.S. Nagorna, N.N. Volynets, A.N. Ostapchuk, V.V. Klochko, T.V. Rybalchenko and L.V. Avdeeva (2010). In vitro antifungal activity of phenylheptatriyne from Bidens cernua L. against yeasts, Fitoterapia 81, 336-338.

[4] J-C. Chalchat, S. Petrovic, Z. Maksimovic and M. Gorunovic (2009). Composition of essential oil of Bidens cernua L., Asteraceae from Serbia, J. Essent. Oil Res. 21, 41-42.

[5] V.V. Smirnov, L.A. Bakina, A.S. Bondarenko, G.T. Petrenko and O.V. Evseyenko (1995). A new sesquiterpene phenol from Bidens cernua L. with antimicrobial activity, Rastit. Resur. 31, 31-37.

[6] Y.L. Li, J. Li, N.L. Wang and X.S. Yao (2008). Flavonoids and a new polyacetylene from Bidens parviflora Willd., Molecules 13, 1931-1941.

[7] S. Olejniczak, K. Ganicz, M. Tomczykowa, J. Gudej and M.J. Potrzebowski (2002). Structural studies of 2-(3',4'-dihydroxyphenyl)-7-beta-D-glucopyranos-1-omikron-yl-8-hydroxychroman-4-one in the liquid and solid states by means of 2D NMR spectroscopy and DFT calculations. J. Chem. Soc. Perkin Trans. 2. 6, 1059-1065.

[8] J.B. Harborne (1996). The flavonoids. Advances in research since 1986., Chapman \& Hall, London - Glasgow - New York - Tokyo - Melbourne - Madras, pp. 452-468.

[9] T.J. Mabry, K.R. Markham and M.B. Thomas (1970). The Systematic Identification of Flavonoids, Springer-Verlag, New York

[10] G. Romussi and F. Pagani (1970). Constituents of Bidens frondosa L., Boll. Chim. Farm. 109, 467-75. 
[11] H. Karicome, K. Ogawa and Y. Sashida (1992). New acetylated glucosides of chalcone from the leaves of Bidens frondosa, Chem. Pharm. Bull. 40, 689-691.

[12] N. De Tommasi, V. De Feo, F. De Simone, C. Pizza and Z. L. Zhou (1992). Constituents of Bidens parviflora, Fitoterapia 63, 470.

[13] J. Wang, H. Yang, Z.W. Lin and H.D. Sun (1997). Flavonoids from Bidens pilosa var. radiata, Phytochemistry. 46, 1275-1278.

[14] M. Wolniak, M. Tomczykowa, M. Tomczyk, J. Gudej and I. Wawer (2007). Antioxidant activity of extracts and flavonoids from Bidens tripartita. Acta Pol. Pharm. 64, 441-447.

[15] G. Cioffi, F. De Simone, N. De Tommasi, P. Montoro, C. Pizza and S. Abdo (1999). Chalcone esters glycosides from Bidens andina. Boletin de la Scienze Quimica del Peru. 65, 111-114.

[16] S. Miosic, K. Knop, D. Hölscher, J. Greiner, Ch. Gosch, J. Thill, M. Kai, B. K. Shrestha, B. Schneider, A. C. Crecelius, U. S. Schubert, A. Svatoš, K. Stich and H. Halbwirth (2013). 4-Deoxyaurone formation in Bidens ferulifolia (Jacq.) DC. PLoS One 8, e61766.

[17] B.A. Bohm and T.F. Stuessy (2001). Flavonoids of Sunflower Family (Asteraceae). Springer-Verlag Wien-New York.

[18] Polish Pharmacopoeia 10 ${ }^{\text {th }}$ ed. (2014). Polish Pharmaceutical Society, Warsaw.

[19] DAB10 (1998). Deutsches Arzeneibuch Antliche Ausgabe. Deutcher Apotheker Verlag, Stuttgart.

[20] R.P. Adams (2007). Identification of essential oil components by gas chromatography/mass spectroscopy. Allured Publishing Co. Carol Stream, Illinois.

[21] W. Jennings and T. Shibamoto (1980). Qualitative analysis of flavour and fragrance volatiles by capillary gas chromatography. Academic Press, New York.

[22] F. Deba, T.D.Xuan, M. Yasuda and S. Tawata (2008). Chemical composition and antioxidant, antibacterialand antifungal activitiesof essential oils from Bidens pilosa Linn. var. radiata. Food Contr. 19, 346-352

[23] M. Tomczykowa, J. Gudej, T. Majda and J. Góra (2005). Essential oils of Bidens tripartita L. J. Essent. Oil Res.17, 632-635

[24] A.L. Nascimento, L. Raggi, M.C.M. Young and P. R.H. Moreno (2015). Chemical characterization of the volatile compounds of the flowers of Bidens segetum Martius ex Colla (Asteraceae) J. Essent. Oil Res. 27,70-75

[25] E.G. Cantonwine and K.R. Downum (2001). Phenylheptatriyne variation in Bidens alba var. radiata leaves. J Chem Ecol. 27, 313-326

[26] M.T. Grombone-Guaratini, K.L.Silva-Brandao, V.N. Solferini, J. Semir and J.R. Trigo, (2005). Sesquiterpene and polyacetylene profile of the Bidens pilosa complex (Asteraceae: Heliantheae) from Southeast of Brazil. Biochem. Syst. Ecol. 33, 479-486

[27] V. Kaškonienė, P. Kaškonas, A. Maruška, A. and O. Ragažinskienè (2013). Essential oils of Bidens tripartita L. collected during period of 3 years composition variation analysis. Acta Physiol. Plant. 35, 1171-1178, doi:10.1007/s11738-012-1156-y

[28] D. Hochmuth (2006). MassFinder 3. Terpenoids and related constituents of essential oils. Hamburg.

[29] NIST MS Search 2.0.

[30] A. Wajs, J. Urbańska, E. Zaleśkiewicz and R. Bonikowski (2010) Composition of essential oil from seeds and cones of Abies alba, Nat. Prod. Commun. 5, 1-4.

[31] Clinical and Laboratory Standards Institute (2009). Performance Standards for Antimicrobial Susceptibility Testing, In: 19th Informational Supplement M100-S19, CLSI, Wayne, PA, USA

[32] A.Nagaraj, M.Sunitha, L.S.Rao, M.V. Devi and C.S.Reddey (2015)Synthesis and biological evaluation of 3-benzyl/piperazino-methyl-1,2,3-triazol-4-yl)-2,3-dihydro-1,3,4-thiadiazole-2-thione, Org.Commun. 8, 70-77.

[33] A. Espinel-Ingroff, T. White and M.A. Pfaller (1999). Antifungal agents and susceptibility tests, In: Manual of Clinical Microbiology, ed. P.R. Murray, E.J. Baron, M.A. Pfaller, F.C. Tenover, R.H. Yolken, American Society for Microbiology, Washington DC, pp. 1690-1652.

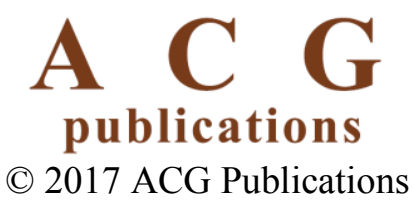

